\title{
Haurren arretaren eta ongizatearen sustatzea biofeedback bidezko esku-hartze programa bat erabiliz
}

\author{
Promoting children's attention and wellbeing \\ through a biofeedback intervention programme \\ Aitor Aritzeta*, Goretti Soroa, Ainara Aranberri \\ Psikologia Fakultatea (UPV/EHU)
}

\begin{abstract}
LABURPENA: Egun arreta berezia jasotzen ari den ikerketa-lerroa da haurren erregulazio emozionalak garapen psikologikoan izan dezakeen eraginarena. Gainera, biofeedback teknikaren inguruko ikerlanek aditzera eman dute biofeedbackak onurak izan ditzakela haurren arlo kognitiboan, emozionalean zein sozialean. Hobetu al daitezke Lehen Hezkuntzako neska-mutilen arreta maila, erregulazio emozionala eta portaera biofeedback bidezko esku-hartze programa bat erabiliz? Galdera honi erantzuna ematearren, gaiaren inguruan literatura zientifikoak eskaini dituen emaitza esanguratsuenak biltzetik hasiko gara. Bigarren zatian, ikerlan honetan diseinatu den esku-hartze programa aurkeztuko da, bai eta bere ebaluazio sistema ere. Hirugarren zatian, berriz, lan honetatik eratorritako emaitzak azalduko dira. Azkenik, ikerlan honetatik ateratako ondorio batzuk aurkeztuko dira.
\end{abstract}

GAKO-HITZAK: haurtzaroa, erregulazio emozionala, esku-hartzea, biofeedbacka.

ABSTRACT: Currently, one of the research lines of special relevance is the one that seeks to know the influence of emotional regulation on the psychological development of children. Likewise, the studies focused on the biofeedback technique inform about its benefits on children's cognitive, emotional and social areas. Taking into account the above mentioned, an intervention program based on biofeedback was designed and implemeted with the intention to improve the attentional levels and the emotional and behavioral regulation of girls and boys in Primary Education. In order to reach this goal, this work begins with a review of the scientific literature on this field. Moreover, an intervention program for emotional regulation based on Biofeedback was designed, implemented and evaluated. Finally, the results derived from this work are presented and some conclusions are drawn based on the results observed.

KEYWORDS: childhood, emotional regulation, intervention, biofeedback.

* Harremanetan jartzeko / Corresponding author: Aitor Aritzeta. UPV/EHU. Oinarrizko Psikologia Prozesuak eta haien Garapena. Psikologia Fakultatea. Tolosa hiribidea, 70. E-20018 Donostia/San Sebastián - aitor.aritzeta@ehu.eus

Nola aipatu / How to cite: Aritzeta, Aitor; Soroa, Goretti; Aranberri, Ainara (2018). «Haurren arretaren eta ongizatearen sustatzea biofeedback bidezko esku-hartze programa bat erabilizw; Tantak, 30(2), 153-175. (https://doi.org/10.1387/tantak.20180).

Jasotze-data: 2018/05/14; Onartze-data: 2018/09/21.

ISSN 0214-9753 - elSSN 2444-3581 / (c) 2018 UPV/EHU

(c) (i) Obra hau Creative Commons Atribución 4.0 Internacional-en lizentziapean dago 


\section{SARRERA TEORIKOA}

Lehen atal honetan, erregulazio emozionalaren garrantzia azpimarratu nahi da. Gainera, haurtzaroan emozioak kudeatzeak dakartzan onurak aipatuko dira; zehazki hiru arlo hauetan: a) Kognitiboan (arreta maila), b) Emozionalean (antsietatea, depresioa, autoestimua, autokonfiantza eta gai izatearen sentsazioa) eta c) Sozialean (estres soziala, jarrera eskolarekiko eta harremanak lagunekin, gurasoekin zein irakasleekin).

\subsection{Erregulazio emozionala}

Norberaren emozioak eta erreakzio fisiologikoak elkarri lotuak daudela frogatua geratu zen duela asko (Cannon, 1929). Ordutik gaurdaino, ikerlan ugari egin dira erreakzio fisiologikoek emozioen intentsitate-mailan eragiten duten modua aztertzeko, bai eta erreakzio fisiologikoarekiko kontzientzia hartzeak emozio bat aktibatu dezakeen egiaztatzeko ere (Zeman, Cassano, Perry-Parrish eta Stegall, 2006). Zentzu honetan, neurozientziaren azken aurrerapenen arabera, nabarmenak dira emozioen, pentsamenduaren eta portaeraren arteko konexioak (Immordino-Yang eta Damasio, 2007). Konexio hauek egokitzapen pertsonal, akademiko zein sozialerako ezinbestekoak bilakatzen dira (Palomera, Fernández-Berrocal eta Brackett, 2008). Golemanen (2016) aburuz, emozioek (amigdalaren aktibazioa) gure pentsamendua «bahitu» dezakete. Horren ondorioz, gure pentsatzeko gaitasuna sentitzen ari garen emozioaren intentsitateak bahituta geratu daiteke (adibidez, gorrotoaren kasuan). Honela, kognitiboki informazioa argi prozesatu ahal izateko, ezinbestekoa da emozioaren intentsitatea jaistea erregulazio emozionala erabiliz.

Emozioak erregulatzeko bost bide ezagutzen dira (John eta Gross, 2008): 1) Erreakzio fisiologikoen erregulazioa; 2) Gertakariaren aurrean erreakzionatzea; 3) Informazioa prozesatzearen erregulazioa; 4) Emozioen adierazpenen eta portaeren erregulazioa; eta 5) Babes soziala bilatzea. Biofeedback teknika «erreakzio fisiologikoen erregulazioaren» bidean kokatzen da.

\section{Zertan datza biofeedbackaren teknika? (atzeraelikadura biologikoa)}

Biofeedbackean edo atzeraelikadura biologikoan (Andrasik eta Flor, 2003) oinarritutako teknikak teknologia aurreratua eta berritzailea erabiltzen du norbanakoaren sentitzeko, pentsatzeko eta ekiteko joerak hainbat adierazle fisiologikorekin erlazionatzeko; hala nola, bihotzaren erritmoa, azalaren tenperatura, giharren herstura eta arteria-tentsioa. Beste era batera esanda, gure gorputzean gertatzen diren aldaketa fisiologikoak software batean erregistratzen dira eta, indikatzaileak modu ulerterraz batera eral- 
Haurren arretaren eta ongizatearen sustatzea biofeedback bidezko...

datu ostean, grafiko mugikorretan islatzen dira soinu, bibrazio edo zenbaki gisa. Jarraian azaltzen den irudiak (ikus 1. irudia) biofeedbackaren zikloa irudikatzen du.

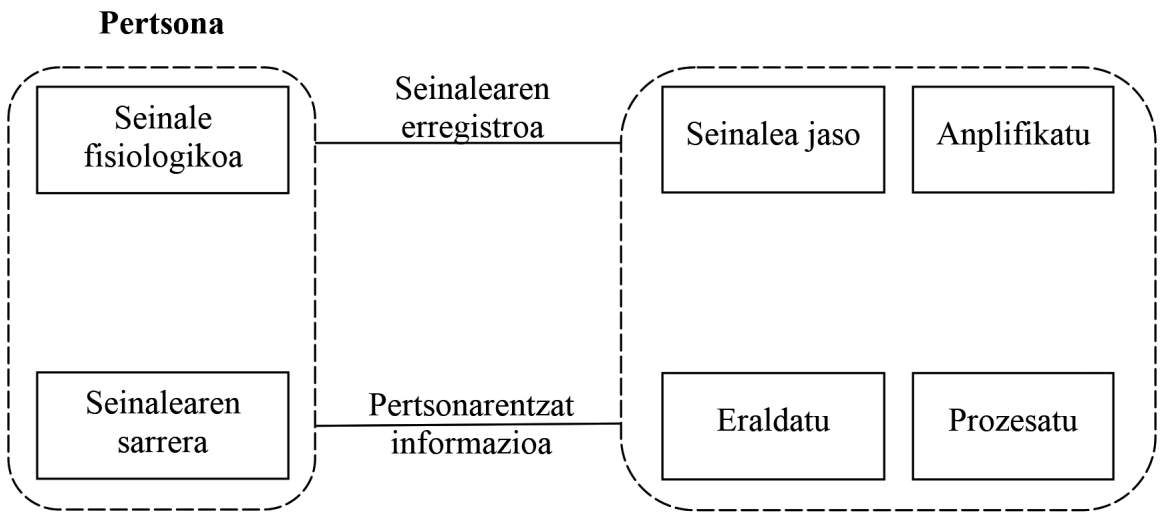

1. irudia

Biofeedback-aren zikloa

Biofeedback entrenamenduaren bitartez ikasten da momentuan izaten ditugun erantzun fisiologikoak antzematen eta hauek kontrolatzen (gutxituz edo areagotuz). Gainera, praktikarekin ikasten da identifikatzen zein diren erreakzio fisiologikoak (adib. bihotz taupadak) zein psikologikoak (adib. pentsamendu zehatzak) eragiten dizkiguten estimuluak, baita horiek kontrolatzen ere. Horrela, estimuluen aurreko erantzun egokitzaileak eta zehatzak errepikatzen doazen heinean, hauek hobeto ulertu daitezke eta ikasketa honek erantzun fisiologiko erlaxatuagoak ematen lagunduko du, eta nork bere pentsatzeko eta jokatzeko gaitasuna egokitu ahal izango du.

Azken finean, biofeedback teknikak norberaren «koherentzia fisiologikoa» (McCraty, Atkinson eta Tomasino, 2006) sustatzen du eta, besteak beste, nerbio sistemaren, burmuinaren eta gorputzaren arteko armonia errazten du. Denborarekin eta gure koherentzia fisiologikoa indartzen goazen heinean, hobetzen joango gara emozio-fisiologiaren autoezagutza, eta, horrekin batera, areagotu egingo da estres maila erregulatzeko dugun gaitasuna.

\subsection{Erregulazio emozionalaren garrantzia haurtzaroan}

\section{Erregulazio emozionalaren garrantzia arlo kognitiboan}

Egun arreta berezia jasotzen ari da erregulazio emozionalak haurren ikaskuntza eta arreta prozesuekin lotzen duen ikerketa-lerroa (Graziano, 
Reavis, Keane eta Calkins, 2007). Hainbat ikerlanetan haurren elektroentzefalogramak aztertu dira eta burmuinaren uhinak eta ikaskuntza patroiak alderatu dira (Butnik, 2005; Friel, 2007). Emaitzen artean honako patroi hau aurkitu da: Theta uhinen maila altuak eta beta uhinen maila baxuak erlazioren bat izan dezaketela kontzentratzeko zailtasunekin (distrakzioa), geldi egoteko arazoekin (inpultsibitatea) eta antsietatearekin (hiperaktibitatea). Aurkikuntza honetatik abiatuta, biofeedbackaren teknika erabiltzen hasi ziren arreta zailtasunak dituen haur baten arreta-patroiak aldatzeko eta egunerokotasuna errazteko. Hori horrela, AGNHa (Arreta Gabeziaren Nahastea Hiperaktibitatearekin edo gabe) duten haurrekin egindako ikerlanetatik eratorritako emaitzek aditzera ematen dute, biofeedbackaren teknikaren entrenamenduak norbanakoaren koherentzia psikofisiologikoan (sistema fisiologikoaren, emozionalaren, kognitiboaren eta konduktualaren arteko elkarreragina) eragin positiboa duela eta arreta gaitasuna hobetzen duela, inpultsibitatea eta hiperaktibitatea gutxitzearekin batera (Amon eta Campbell, 2008; Harvard Mental Health Letter, 2010).

Ameriketako Estatu Batuetan biofeedbackaren teknikak ikasgeletan eragiten dituen onurak ikertu dituzte (Harvard Mental Health Letter, 2010). Aipaturiko ikerketaren helburua haurrari bere emozioak kudeatzen irakastea da, bere arnasketaren eta bihotz taupadaren kontzientzia hartuz eta beren barne egoera fisiologikoa unean ezagutuz, software-aren laguntzaz. Horrela, emozioek haurraren ikaskuntzarekin eta errendimendu akademikoarekin erlazio zuzena dutela aurkitu da (Arguelles, McCraty eta Rees, 2003). Esaterako, estres-maila baxua dagoenean, nerbio-sistemak mezu koherenteak bidaltzen dizkio burmuinari, eta horiek positiboki eragiten diete ikaskuntza prozesuei (arreta, pertzepzioa, ulermena, erabakien kudeaketa eta oroimena) eta, honenbestez, eskola errendimenduari. Haatik, gogo-aldarte negatiboek mezu inkoherenteagoak helarazten dituzte burmuinera, eta, horrekin batera, nerbio-sistemarekin koordinazioa zaildu eta prozesu kognitiboak oztopatu.

Unibertsitate mailako ikasleekin frogatu izan da, halaber, ikasleen arreta maila hobetzearekin batera, ikasketekiko estres-maila murriztu egiten dela eta lotzen dituzten emaitza akademikoak hobetu egiten direla (Aritzeta et al., 2016; Larsen eta Sherlin, 2013; Sterman eta Egner, 2006).

\section{Erregulazio emozionalaren garrantzia arlo emozionalean}

Azken urteetan mundu mailan gorantz egin du antsietatea eta depresioa jasaten duten pertsonen kopuruak eta, antza denez, gero eta adin goiztiarragoetan agertzeaz gain (Espainiako Osasun eta Gizarte Politiken Ministerioa, 2009), bata bestearekiko komorbilitate gisa eman ohi da (Wadsworth eta Hudziak, 2001). Tamalez, antsietate- eta depresio-sintomak uste baino ohikoagoak izaten dira Lehen Hezkuntzako haurrengan (Sánchez-Hernández, Méndez eta Garber, 2014): suminkortasuna, kasketaldiak, negarra, 
hiperaktibitatea, tristuraren aurpegi adierazpenak, loaren asaldurak eta esfinterren kontrolarekin zailtasunak. Gainera, haurtzaroan sortutako antsietate- zein depresio-nahasteetan goiz eta modu eraginkorrean esku hartzen ez bada, Osasunaren Munduko Erakundeak aditzera eman duenez, 2020. urterako depresioa izango da pertsonengan ezgaitasunak eragingo dituzten gaixotasunen artean bigarrena, gaixotasun iskemikoen atzetik. Irakasleak detekzio goiztiarrak egiteko eragile ezin hobeak izan daitezke eta, hein handi batean, nahaste emozionalak prebenitzeko eskolatik hainbat ekintza eta programa martxan jar ditzakete (ikus Soroa, Bernaras eta Jauregizar, 2012).

Biofeedbackaren bidezko entrenamenduak haurren nahaste emozionaletan duen eraginkortasuna frogatu dute hainbat ikerlanek (Blom, Olsson, Serlachiurs, Ericson eta Ingvar, 2010; Karavidas et al., 2007; Reinecke eta Ginsburg, 2008). Izan ere, antsietatearen eta depresioaren osagai fisiologiko eta somatikoak direla eta, gomendagarriak izan ohi dira erlaxazioan oinarritutako teknikak, hain zuzen ere, urduritasun-maila eta pentsamendu ezkorren kopurua gutxitzeko. Biofeedbackaren teknika, gainera, haurraren indikatzaile fisiologikoen autoezagutzarako baliagarria da hobetzeko egunerokotasunean haurrak izan ohi dituen erreakzioen ezagutza eta kontrola; eta, zer esanik ez, buruko minak, lotarako arazoak, bizkarreko kargak eta elikadura joerak hobetzeko.

\section{Erregulazio emozionalaren garrantzia arlo sozialean}

Jakin badakigu, haurrek ereduen bitartez heureganatzen dutela egoera jakin batean sentitutako emozioak identifikatzeko eta adierazteko gaitasuna. Eredu horiek, beste batzuen artean, gertuko haurrak, hezitzaileak edo familia-kideak izan daitezke (Gross eta Thompson, 2007). Lehen Hezkuntzaren hasieran, haurrak jada kontrolatzen dituzte aurpegierak, testuinguru sozialaren arabera. Gainera, antzematen hasten dira iraunkorrak izan daitezkeela sentitzen dituzten emozioak . Horrez gain, jabetzen dira mementoko gogo-aldarteak beren portaeran duen eraginaz, eta, era berean, konturatzen hasten dira gai direla kudeatzeko gogo-aldartea ere. Eskola garai honetan (6 urtetik aurrera), haurrak gero eta erraztasun handiagoa dute hausnartzeko beren barne-bizipenen inguruan. Hori horrela, erregulazio emozionala lantzeko lagungarriak ziren erreferentziazko ereduetatik aldendu, eta, pixkanaka, erregulazio emozionala arlo intrapertsonalera bideratzen hasten dira (Cole eta Kaslow, 1988).

Hainbat ikerlanen arabera, biofeedbackaren teknika erabiliz ikasleen, emozioak erregulatzeko gaitasuna hobetzearekin batera, gelan eta patioan gertatzen diren gatazka-kopurua ere gutxitu egiten da, eta gatazka hauek kudeatzeko gaitasuna hobetu egiten da (Gunkelman eta Johnstone, 2005; Loo eta Barkley, 2005). Ildo beretik, bideo-jolas moduko biofeedbackaren bidezko entrenamendua erabili zuten ikerlan batean (Pop-Jordanova eta 
Gucev, 2010) emaitza positiboak lortu ziren besteekiko harreman sozialak hasi eta modu osasuntsuan mantentzeak haur bati eragin diezaiokeen estres soziala gutxitzeko neurrian. Ikerketa horretan ikusi zen bereziki onuragarria zela, batez ere, haurrak bere inguruko lagun, guraso eta irakasleekiko duten pertzepzio positiboa areagotzeko.

\subsection{Esku-hartze programaren helburuak}

Aztertutako ikerlan zientifikoen arabera, 6 eta 12 urte bitarteko haurrak prestatuak daude beren burua erregulatzen ikasteko; alegia, autoezagutza emozionala hobetzeko eta, honekin batera, koherentzia psikofisiologikoa sustatzeko (oreka fisiologikoa, kognitiboa, emozionala eta konduktuala). Ikusi dugu, halaber, emozioak erregulatzen ikastea zein lagungarria den haurraren garapen psikologikoan. Izan ere, adin goiztiar hauetan, ikaskuntza hau neurologikoki egonkortzera iritsi daiteke (neuronen mielinizazioagatik).

Hori horrela, lan honen helburua biofeedbackaren teknikan oinarrituta diseinatu dugun esku-hartze programa baten eraginkortasun-maila aztertzea da; zehazki, Lehen Hezkuntzako neska-mutilen garapen psikologikoaren hiru arlo hauetan: arreta mailan, portaeran eta estres fisiologikoan.

Biofeedbackaren metodoan oinarritutako entrenamendu honek ikasle bakoitzaren erregulazio emozionalaren emaitzak hobetzea bilatzen du, horretarako arnasketa eta irudikapena bezalako teknikak erabiliz. Hainbat adituk adierazi bezala, zenbat eta gehiago entrenatu, orduan eta gaitasun handiagoa lortuko du haurrak bere emozioak kudeatzeko (Ricarte, Ros eta Latorre, 2015). Ondoren, saio hauetan barneraturikoak egunerokotasunera hedatzea bilatzen da. Aurreikustekoa da haurra gai izango dela bere parametro fisiologikoak gutxitzeko, baldin eta estres-egoera batean edo muturreko emozioren bat bizitzen ari denean gogora ekartzen badu entrenamenduaren bidez egoera edo emozio horrekin konektatu den irudia (koloretako puxika) (Pauloviar ikaskuntza klasikoa).

\section{IKERKUNTZA-METODOA}

Bigarren zati honetan, ikerkuntza-metodoa bere osotasunean aurkezten da. Lehenbizi, ikerketako parte-hartzaileen ezaugarriak laburbilduko dira eta programaren diseinua deskribatuko da. Ondoren, programaren ebaluazioaren diseinua aurkeztuko da eta, horrekin batera, ebaluazio tresnak eta ondorengo analisi estatistikoak zerrendatuko dira. 


\subsection{Parte-hartzaileak}

Ikerlan honetan, 7 eta 12 urte bitarteko $\left(\mathrm{Bb}_{\text {adina }}=8,9\right.$ urte eta $\left.\mathrm{Dt}=1,49\right)$ 196 ikaslek parte hartu dute guztira. Horietatik \% 49 neskak dira eta \% 51 mutilak. Haur hauek Beasaingo (Gipuzkoa) Murumendi Ikastolan Lehen Hezkuntza ikasten ari dira, D ereduan (guztiz euskaraz ematen den irakaskuntza eredua, gaztelania eta ingelesa irakasgai gehigarri gisa dituena). Honela banatzen da lagina hiru zikloetan: lehen zikloko 2. Mailan ikasleen $\%$ 23; bigarren zikloan ikasleen \% 42,3 (3. mailan \% 19,9 eta 4. mailan $\%$ 22,4); hirugarren zikloan gainerako $\% 34,7$ (5. mailan $\%$ 19,4 eta 6 . mailan $\% 15,3)$.

Ikerketa hau aurrera eramateko, lagin osoa bi taldetan banatu zen: talde esperimentala eta kontrol taldea. Taldeak orekatuak izan zitezen, ziklo bakoitzeko ikasle-kopuruaren erdia talde esperimentalera esleitu zen (24 ikasle lehen zikloan, 44 bigarren zikloan, 31 hirugarren zikloan) eta beste erdia kontrol taldera (21 ikasle lehen zikloan, 39 bigarren zikloan, 37 hirugarren zikloan).

\subsection{Esku-hartze programaren egitura}

Jarraian zehazten den egitasmoa Lehen Hezkuntzako ikasleei zuzendu zaie, eta eurak hobekien ezagutzen dituzten hezitzaileak izan dira trebakuntzaren ardura hartu dutenak. Jarraian esku-hartze programaren xehetasunak eskainiko dira. Batetik, irakasleek jasotako trebakuntza laburbilduko da eta, bestetik, ikasleei zuzendutako esku-hartze programa bera deskribatuko da.

\section{Irakasleek jasotako trebakuntza}

Bi fasetan banatu da irakasleek jaso eta emandako trebakuntza. Lehen fasean, 6-8 orduko trebakuntza jaso dute ekimen honetan parte hartu duten irakasleek. Trebakuntza horren bidez, biofeedbackaren teknika gertutik ezagutzeaz gain, bere osotasunean erabiltzen ikasi dute irakasleek, beren buruari aplikatzen ikasi dute, eta bereziki haurrei nola egokitu eta ezarri ulertu dute. Bigarren fasean, berriz, aurrez ikasitakoa haurrekin jarri dute martxan irakasleek; betiere, modu programatuan eta emaitzak erregistratuz.

\section{Ikasleei zuzendutako esku-hartze programa}

Haurrek, guztira, biofeedbackaren teknikan oinarritutako bost saiotan hartu dute parte. Jarraian azalduko da zer landu den saio bakoitzean. 
Aitor Aritzeta, Goretti Soroa, Ainara Aranberri

\begin{tabular}{c|c|c}
\hline \multicolumn{1}{c|}{ 1. saioa } & \multicolumn{1}{|c|}{ 2. eta 3. saioak } & \multicolumn{1}{c}{ 4. eta 5. saioak } \\
\hline $\begin{array}{l}\text { Helburuen aurkezpena, } \\
\text { emozioen erregistroa eta } \\
\text { biofeedback-konexioak }\end{array}$ & $\begin{array}{l}\text { Arnasketa-teknika, kohe- } \\
\text { rentziaren entrenamendua, } \\
\text { biofeedback-konexioak }\end{array}$ & $\begin{array}{l}\text { Imajinatze-teknika, ar- } \\
\text { nasketa-teknika eta bio- } \\
\text { feedback-konexioak }\end{array}$ \\
\hline
\end{tabular}

2. irudia

Biofeedbackaren teknikan oinarritutako esku-hartze programaren egitura

- Lehen saioa: Ikasleei gogorarazten zaie trebakuntzan zehar eskuratutako gaitasunak bizitzako egoera errealetara eramatea dela asmoa; alegia, estresa eta gatazka bizi diren egoeretara. Ildo horretatik, hauxe galdetzen zaio haurrari: «Zer egoeratan nahiko zenuke lasaiago egon?». Erantzuna erregistratu ondoren, haurra lehen aldiz konektatzen da Emwave softwarera, eta ondorengo argibidea ematen zaio: «Orain jolas batera konektatuko gara eta bidaiatxo bat egingo dugu puxika hegalarian. Begiratu norantz doan puxika eta nola aldatzen den paisaia. Bidaia laburra izango da, 3-5 minutukoa».

- Bigarren eta hirugarren saioak: Haurrek arnasketa-teknika ikasten dute. Teknika honen helburua da arnasa modu geldo, sakon eta erregularrean hartzea. Arnasaren bitartez erlaxatuz gero, gure aktibazio (afektibo edo emozionala) maila gutxitzen da. Haurrekin landutako arnasketa teknika diafragmatikoa izan beharrean, ziklikoa, sakona eta lasaia izatea bilatzen da, Emwave softwarean agertzen den Coherence Coach programa erabiliz. Teknika barneratu ostean, haurrak biofeedbackaren konexioa egiten du. Horretarako, argibide hau ematen zaio: «Orain jolasera konektatuko gara eta bidaiatxo bat egingo dugu puxikan. Ikasi dugun arnasketa egingo dugu, saia zaitez zure burua lasaitzen eta lasai mantentzen».

- Laugarren eta bosgarren saioak: Haurrari Emwave softwarean azaltzen den puxika birtualaren antzeko koloretako argazki bat ematen zaio, A4 formatuan. Irudi honekin, Imajinatze (irudikapena) teknika landuko da. Haurra erlaxatuko duen ekintza edo egoera bat sortu edo irudikatu beharko da. Kasu honetan, aurretik definitutako zehaztasunez begiratu eta norberaren barrura eramateko saiakera egingo da, forma, kolore zein xehetasunetara bideratuz bere arreta eta, horrekin batera sortzen diren sentsazio atseginekin konektatuz. Argazki hau lehen, bigarren eta hirugarren saioetan egindako konexioan ikusten duten argazki bera da. Argazkia haurraren aurrean jarriko da eta argibide hau emango zaio: «Begiratu argazkiari eta aztertu lasai bertan agertzen diren koloreak eta formak. Ikasi dugun arnasketa errepikatuko duzu... Arnasketa hori eginez eta argazkia begiratuz puxikan bidaia egingo dugu, baina ordenagailuan ikusi gabe. Imajinatuz. 
Urruti iristeko, hartu arnasa eta bota, ikasi dugun bezala, zure burua lasaitu eta begiratu argazkia. Nahi duzun bidaia imajinatu dezakezu koloretako puxika honetan».

\section{a) EBALUAZIOAREN DISEINUA ETA PROZEDURA}

Ikerketa hau gauzatzeko, pretest/postest diseinu kuasiesperimental bat erabili zen kontrol-talde baliokidearekin.

Programaren esku-hartze prozedura, bestalde, hiru fasetan bereizten da. Lehendabizi, pretest ebaluazio-fasea egiten da. Fase honetan haurrari eskatzen zaio galdera-sorta bat bete dezan aldagai kognitibo, emozional eta sozialen inguruan galdetuz. Bigarrenik, esku-hartze programaren aplikazio fasea egiten da. Fase hau bost saiotan garatzen da. Saio guztiak leku fisiko berean eta ordutegi berean egiten dira, eta haurren ohiko irakasleak bideratuko du saio horietan egingo den entrenamendua. Hirugarren fasean, postest ebaluazioa egiten da. Horretarako, haurrari eskatzen zaio lehen faseko galdera-sorta bera berriro bete dezan. Izan ere, diseinu honen bidez neurtu nahi da ikerketa-helburu diren aldagaiak aldatu diren programa aplikatu ostean. Azken saioan, programari itxiera eman eta galdera-sorta objektiboa osatzearekin batera, ebaluazio jarraitua ere burutzen da galdera subjektiboak erabilita (ekintzen asebetetze eta zailtasun maila). Esku-hartzean zehar, irakasle formatzaileek taula bana daukate saio bakoitzaren inguruko gertakariak jasotzeko, baita garrantzitsuak iruditzen zaizkien testuinguruko datuak biltzeko ere. Informazio hau ebaluazio jarraituaren barruan bilduko litzateke.

Ikerlan honek gizakiekin egiten diren ikerketetan beharrezkotzat hartzen diren oinarri etikoak errespetatzen ditu. Hala nola, informazioa jasotzeko eskubidea, datu pertsonalen babesa, konfidentzialtasuna, anonimotasuna, esku-hartzea edozein momentutan bertan behera uzteko eskubidea eta informatutako baimena. Aipatu nahi da, halaber, ikerlan honek Euskal Herriko Unibertsitateko (UPV/EHU) etika batzordearen onespena duela.

\section{b) EBALUAZIO-TRESNAK}

Esku-hartze programa hau ebaluatzeko erabilitako tresnak lau hauek izan dira: galdera-sorta soziodemografikoa, D2, BASC eta Emwave softwarea.

\section{Galdera-sorta soziodemografikoa (ad hoc)}

Haur bakoitzaren aldagai soziodemografikoak ezagutzearren, 9 galderez osatutako galdera-sorta bat diseinatu da. Hauek dira jasotako datuak: sexua, adina, jatorria, ikastetxea, ikasturtea (errepikatzaileak diren adieraziz), etxean bizi diren kideak, anai-arreben kopurua, gurasoen heziketamaila eta gurasoen egungo lan-egoera. 
Arreta testa (Test de atención D2; Brickenkamp, 2002)

Tresna honek ikaslearen arreta selektiboa neurtzen du, zeinak kontzentrazio maila egokia, zereginarekiko motibazioa eta arretarekiko kontrola barne hartzen dituen. Zehazki, D2 deritzon tresnak lau aldagai hauek neurtzen ditu; guztiek ezaugarri psikometriko egokiak dituzte. Hauek dira aldagaiak: TR (lerro bakoitzean hautatutako estimulu-kopurua), TA (asmatutako estimulu-kopurua), O (hautatu ez den estimulu-kopurua), C (gaizki dagoen estimulu-kopurua). Lau indikatzaile hauekin haurren eraginkortasun maila (TOT) eta kontzentrazio maila $(\mathrm{CON})$ ere neurtu daitezke.

Tresna hau indibidualki bete beharrekoa da, nahiz eta talde-mailako pasazioa egin daitekeen eta argibideak zein denboraren neurketa kolektiboa diren. Probak 8-10 minutuko iraupena du. Guztira 14 lerro aurkezten dira eta bakoitzean 47 ikur; alegia, 658 elementu. Ikur hauek «d» edo «p» hizkiak izan daitezke, zeintzuk bat edo bi marratxo dituzten hizki bakoitzaren gainean edo azpian. Haur bakoitzaren erronka izango da lerro bakoitza ezkerretik eskuinera arretaz begiratzea eta soilik bi marratxodun «d» hizkiak hautatzea.

Haurtzaroan dauden haurren inguruan egindako ikerlan batean ondorioztatutako ezaugarri psikometrikoek baieztatzen dute D2 tresna egokia dela 6-11 urte bitarteko haurrekin erabiltzeko (Jiménez et al., 2012).

Haurren portaeraren ebaluazio-sistema (BASC-S2; Behavior Assessment System for Children; Reynolds eta Kamphaus, 1992) (Euskarazko bertsioa; Jauregizar, Bernaras, Ibabe eta Sarasa, 2012)

Dimentsio anitzeko galdera-sorta honen bitartez, haurraren honako aldagaiak neurtu ditugu ikerlan honetan: eskolarekiko jarrera ezkorra («eskola gorroto dut»), irakaslearekiko jarrera ezkorra («irakasleak ez dira bidezkoak»), estres soziala («jendeak gauza desatseginak esaten dizkit»), antsietatea («gehienetan arduratuta nago»), depresioa («lehen orain baino zoriontsuago nintzen»), gai ez izatearen sentsazioa («ez dut ezertarako balio»), pertsonarteko harremanak («besteek nitaz barre egiten dute»), gurasoekiko harremana («nire gurasoekin egotea gustuko dut»), autoestimua («ile polita dut»), eta nork bere buruarekiko duen konfiantza («ona naiz erabakiak hartzen»).

Galdera-sorta hau 146 esaldik osatzen dute eta esaldi hauek 12 aldagairi atxikitzen zaizkie: 8 aldagai kliniko eta 4 egokitzapeneko. Erantzun eskala Likert motakoa da eta 1-4 bitarte erantzun daiteke: 1) Inoiz ez, 2) Batzuetan, 3) Sarri, 4) Ia beti. Guztira 20-30 minutu bitarteko denboratartea eskatzen du eta banaka bete beharrekoa da.

Ezaugarri psikometrikoei dagokienez, Jauregizarrek eta bere ikerketa-kideek argitaratu lan batek (2012) 3 faktore identifikatu ditu eus- 
karazko bertsioaren analisi faktorialaren emaitza gisa. Proba horretan lortutako emaitzen arabera, bestalde, hiruren barne trinkotasuna egokia izan da. Horrez gain, egiaztatu zen egokiak zirela Kaiser-Meyer-Olkin balioak zein Barlett frogak emaitza esanguratsuak eman zituztela. Galdera-sortaren eskalen fidagarritasun-indizeak ere egokiak zirela egiaztatu zen. Datu horiek guztiak jatorrizko artikuluan kontsulta litezke (Jauregizar et al., 2012).

\section{Emwave Desktop (Harvard Mental Health Letter, 2010)}

Haurren estres fisiologikoaren mailak neurtzeko, saioz saio bakoitzak lortutako koherentzia-mailak aztertu ziren. Hearthmath Emwave softwarea erabili zen (Arguelles, McCraty eta Rees, 2003) haurren koherentzia-mailak aztertzeko. Software honek haurren bihotz maiztasunaren aldakortasuna metodo ez-inbaditzailea erabiliz neurtzen du (Heart Rate Variability-HRV). Emwave sistemak HRVak eraldatzen ditu eta koherentzia-maila baxu, ertain eta altuak zehaztu, 0tik 100era doan eskalara ekarriz. Beraz, ikasle bakoitzak 100 puntu lortzen ditu koherentzia-ratio baxu, ertain eta altuetan banaturik.

Ikerlan honetarako Emwave softwarea hautatu da, hain zuzen ere, haurrak kolorezko puxika birtual batean hegaldia egiteko aukera ematen duelako. Horri esker, biofeedbackaren teknika modu atseginean ikasi eta berenganatzeko aukera izango dute Lehen Hezkuntzako ikasleek. Horrez gain, software honek, Emotion Visualizer aukera eskaintzen du, eta, horren bidez, haurren kolore aldaketak egin ditzake, haurren gogo-aldarte eta koherentzia maila kontuan hartuz. Bestalde, Coherence Coach deritzon funtzionalitateak haurrari laguntzen dio arnasketaren erritmoa egokitzen modu erraz eta ikusgarrian. Azkenik, software honek aukera ematen du haurrek saioz saio lorturiko koherentzia maila erregistratzeko, eta hori oso baliagarria izan daiteke aurrerago analisi estatistikoak egiteko.

\section{c) ANALISI ESTATISTIKOAK}

Ikerketa honen ebaluazio helburuei erantzuna emateko, lehenik eta behin, datuen normaltasunaren inguruko analisiak egin dira. Datuen normaltasuna bermatuta, estatistiko parametrikoak erabili dira. Pretest eta postest baldintzen arteko alderaketak aztertzearren, erlazionaturiko laginen kasuan aplikatzekoa den Student-en T froga erabili da. Nesken eta mutilen arteko ezberdintasunak aztertzeko, berriz, lagin independenteen kasuan erabiltzekoa den Student-en T froga aplikatu da. Efektuen tamainak neurtzeko, bestalde, Cohen-en $d$ indizea erabili da (txikia .25 baino baxuagoa; ertaina .26-.50; handia .51 baino handiagoa). Analisi hauek egiteko, SPSSren 24.0 bertsioa erabili da. 


\section{EMAITZAK}

Hirugarren atal honetan, biofeedbackaren teknikan oinarritutako eskuhartze programak haurren garapen psikologikoari dagokionez barne hartzen dituen 12 aldagaietan eragindako aldaketak aurkeztuko dira laburbildurik.

\section{a) Programa arreta mailan izandako eragina (D2 tresna)}

Talde esperimentalaren eta kontrol taldearen emaitzak alderatzeko, erlazionaturiko laginen kasurako aplikatzekoa den Student's $T$ froga gauzatu da. Jarraian aurkezten den taulan ikus daitekeenez (ikus 1. taula), aldagai ia guztien kasuan atzemandako ezberdintasunak estatistikoki esanguratsuak izan dira: TR (lerro bakoitzean hautatutako estimulu-kopurua), TA (asmatutako estimulu-kopurua), TOT (arretaren eraginkortasun-maila) eta CON (kontzentrazio-maila. Aldiz, badira bi aldagai alde estatistikoki esanguratsurik egiaztatu ez dutenak: $\mathrm{O}$ (hautatu ez den estimulu-kopurua) eta $\mathrm{C}$ (gaizki dagoen estimulu-kopurua).

1. taula

Arreta-maila: talde esperimentala eta kontrol-taldea

\begin{tabular}{|c|c|c|c|c|c|c|c|c|c|c|c|c|c|c|}
\hline & \multicolumn{4}{|c|}{ Talde esperimentala } & \multicolumn{4}{|c|}{ Kontrol-taldea } & \multicolumn{6}{|c|}{ Esperimentala/Kontrola } \\
\hline & \multicolumn{2}{|c|}{ Pretesta } & \multicolumn{2}{|c|}{ Postesta } & \multicolumn{2}{|c|}{ Pretesta } & \multicolumn{2}{|c|}{ Postesta } & \multicolumn{3}{|c|}{ Pretesta } & \multicolumn{3}{|c|}{ Postesta } \\
\hline & $\mathrm{Bb}$ & Dt & $\mathrm{Bb}$ & Dt & $\mathrm{Bb}$ & Dt & $\mathrm{Bb}$ & Dt & $\mathrm{t}$ & $\mathrm{p}$ & $\mathrm{d}$ & $\mathrm{t}$ & $\mathrm{p}$ & $\mathrm{d}$ \\
\hline TR & 246.7 & 98.39 & 303.51 & 88.23 & 270.20 & 98.28 & 313.48 & 82.39 & -9.60 & .000 & -.33 & -8.69 & .000 & -.31 \\
\hline TA & 80.54 & 35.30 & 117.04 & 35.24 & 96.95 & 36.00 & 123.60 & 37.13 & -10.40 & .000 & -.56 & -11.44 & .000 & -.38 \\
\hline $\mathrm{O}$ & 20.23 & 45.00 & 11.59 & 21.70 & 11.61 & 31.18 & 8.90 & 12.26 & 2.31 & .84 & .22 & 2.88 & .79 & .15 \\
\hline $\mathrm{C}$ & 5.90 & 11.11 & 2.43 & 4.13 & 7.67 & 15.38 & 4.02 & 14.50 & 1.67 & .09 & -.13 & 1.84 & .12 & -.14 \\
\hline TOT & 219.26 & 74.45 & 289.49 & 85.15 & 249.06 & 88.99 & 300.55 & 85.50 & -10.29 & .000 & -.46 & -11.51 & .000 & -.32 \\
\hline $\mathrm{CON}$ & 80.54 & 35.30 & 114.61 & 37.16 & 96.16 & 37.52 & 119.58 & 40.28 & -13.16 & .000 & -.52 & -10.62 & .000 & -.32 \\
\hline
\end{tabular}

\section{b) Programaren eraginak haurraren portaeran (BASC tresna)}

Talde esperimentala: pretesta eta postesta

Atal honetan alderatuko dira talde esperimentalak pretestaren fasean eta postestaren fasean lortutako puntuazioak. Taulari jarraiki (ikus 2. taula), ikus daiteke aldea estatistikoki esanguratsuak izan dela hirugarren alderaketan («antsietatea») ( $p=.017)$. Hauek dira lortutako balioak: $t(85)=-2.441, d=.53$. Hori horrela, antsietate-mailan postestan lortutako 
Haurren arretaren eta ongizatearen sustatzea biofeedback bidezko...

puntuazio altuagoari erreparatuz, esan genezake ikasleek hautemandako antsietate-maila jaitsi egin dela pretestatik postestara bitartean.

Bestalde, 7. («estres Soziala») eta 10. («Gai ez izatearen sentsazioa») konparazioetan ikusi dezakegu pre-post puntuazio aldaketen efektuaren tamaina ertaina dela ( $d=.29$ bi kasuetan), nahiz eta pretestaren eta postestaren arteko ezberdintasunak estatistikoki esanguratsuak ez izan.

2. taula

Haurraren portaera: Talde esperimentaleko pretesta eta postesta

\begin{tabular}{|c|c|c|c|c|c|c|c|c|c|}
\hline \multirow{2}{*}{$\begin{array}{c}\text { Pre-post } \\
\text { Konpara- } \\
\text { ketak }\end{array}$} & \multirow[t]{2}{*}{$\mathrm{Bb}$} & \multirow{2}{*}{ Dt } & \multirow{2}{*}{$\begin{array}{c}\text { Bb } \\
\text { ohiko } \\
\text { akatsa }\end{array}$} & \multicolumn{2}{|c|}{$\begin{array}{c}\% 95 \\
\text { konfiantza tartea }\end{array}$} & \multirow{2}{*}{$t$} & \multirow{2}{*}{$\mathrm{gl}$} & \multirow{2}{*}{$\begin{array}{c}\text { Sig. } \\
\text { (bilaterala) }\end{array}$} & \multirow{2}{*}{$\begin{array}{c}\text { Cohen's } \\
\quad d\end{array}$} \\
\hline & & & & Azpitik & Goitik & & & & \\
\hline 1 & -.070 & .918 & .099 & -.267 & .127 & -.705 & 85 & .483 & .15 \\
\hline 2 & -.035 & 1.163 & .125 & -.284 & .214 & -.278 & 85 & .781 & .06 \\
\hline 3 & -.465 & 1.767 & .191 & -.844 & -.086 & -2.441 & 85 & .017 & .53 \\
\hline 4 & .047 & 1.062 & .114 & -.181 & .274 & .406 & 85 & .686 & .09 \\
\hline 5 & .023 & 1.301 & .140 & -.256 & .302 & .166 & 85 & .869 & .03 \\
\hline 6 & .012 & 1.991 & .215 & -.415 & .439 & .054 & 85 & .957 & .01 \\
\hline 7 & -.186 & 1.260 & .136 & -.456 & .084 & -1.369 & 85 & .175 & .29 \\
\hline 8 & .093 & 1.036 & .112 & -.129 & .315 & .833 & 85 & .407 & .18 \\
\hline 9 & -.047 & .853 & .092 & -.229 & .136 & -.506 & 85 & .614 & .11 \\
\hline 10 & -.256 & 1.737 & .187 & -.628 & .117 & -1.366 & 85 & .176 & .29 \\
\hline
\end{tabular}

Oharra: Lehen zutabeko 10 konparazio horiek BASC tresnaren aldagaietarako pretestan eta postestan lortutako neurriei dagozkie. 1) «Eskolarekiko jarrera ezkorra», 2) «Irakasleekiko jarrera ezkorra», 3) «Antsietatea», 4) «Autoestimua», 5) «Norberarekiko konfiantza», 6) «Depresioa», 7) «Estres soziala», 8) «Pertsonarteko harremanak», 9) «Gurasoekiko harremanak» eta 10) «Gai ez izatearen sentsazioa».

\section{Lehen zikloko talde esperimentala: pretesta eta postesta}

Lehen zikloko talde esperimentaleko ikasleek pretestan eta postestan lortutako puntuazioak alderatuz, aldaketa esanguratsu bat dagoela egiazta daiteke 2. konparazioan («Irakasleekiko jarrera ezkorra»: $p=.011$, $t(15)=-2.905$, eta $d=1.50)$. Aldaketaren efektuaren tamaina handia $(d=1.13)$ duen beste konparazioa 7.a da ( $\ll$ Estres soziala»: $p=.045$ eta $t(15)=-2.18)$. Bi dimentsioen arteko aldaketa honek aditzera ematen du postest fasean ikasleek hobekuntzak dituztela irakasleekiko jarrerari zein estres sozialari dagokienez.

Bestalde, 10. konparazioaren kasuan («Gai ez izatearen sentsazioa»: $p=.58$ eta $t(15)=-.565)$ efektuaren tamaina $(d=0.29)$ ertaina da, nahiz eta ezberdintasuna ez izan estatistikoki esanguratsua. Pretestan lortutako 
puntuazioarekin alderatuz, ikasleek gai izatearen sentsazio handiagoa erakutsi dute postestean.

3. taula

Haurraren portaera: lehen zikloko talde esperimentaleko pretesta eta postesta

\begin{tabular}{|c|c|c|c|c|c|c|c|c|c|}
\hline \multirow{2}{*}{$\begin{array}{c}\text { Pre-Post } \\
\text { konpara- } \\
\text { zioak }\end{array}$} & \multirow{2}{*}{$\mathrm{Bb}$} & \multirow{2}{*}{$\mathrm{Dt}$} & \multirow{2}{*}{$\begin{array}{c}\text { Bb } \\
\text { ohiko } \\
\text { akatsa }\end{array}$} & \multicolumn{2}{|c|}{$\begin{array}{c}\% 95 \\
\text { konfiantza tartea }\end{array}$} & \multirow{2}{*}{$t$} & \multirow{2}{*}{$\mathrm{gl}$} & \multirow{2}{*}{$\begin{array}{c}\text { Sig. } \\
\text { (bilaterala) }\end{array}$} & \multirow{2}{*}{$\begin{array}{c}\text { Cohen's } \\
\quad d\end{array}$} \\
\hline & & & & Azpitik & Goitik & & & & \\
\hline 1 & .063 & 1.124 & .281 & -.536 & .661 & .222 & 15 & .827 & .11 \\
\hline 2 & -.688 & .946 & .237 & -1.192 & -.183 & -2.905 & 15 & .011 & 1.50 \\
\hline 3 & .000 & 1.414 & .354 & -.754 & .754 & .000 & 15 & 1.000 & .00 \\
\hline 4 & .063 & .772 & .193 & -.349 & .474 & .324 & 15 & .751 & .17 \\
\hline 5 & .125 & 1.586 & .397 & -.720 & .970 & .315 & 15 & .757 & .16 \\
\hline 6 & .063 & 1.692 & .423 & -.839 & .964 & .148 & 15 & .884 & .08 \\
\hline 7 & -.563 & 1.031 & .258 & -1.112 & -.013 & -2.183 & 15 & .045 & 1.13 \\
\hline 8 & -.063 & 1.124 & .281 & -.661 & .536 & -.222 & 15 & .827 & .11 \\
\hline 9 & .000 & 1.095 & .274 & -.584 & .584 & .000 & 15 & 1.000 & .00 \\
\hline 10 & -.250 & 1.770 & .443 & -1.193 & .693 & -.565 & 15 & .580 & .29 \\
\hline
\end{tabular}

Oharra: Lehen zutabeko 10 konparazio horiek BASC tresnaren aldagaietarako pretest fasean eta postest fasean lortutako neurriei dagozkie. 1) «Eskolarekiko jarrera ezkorra», 2) «Irakasleekiko jarrera ezkorra», 3) «Antsietatea», 4) «Autoestimua», 5) «Norberarekiko konfiantza», 6) «Depresioa», 7) «Estres soziala», 8) «Pertsonarteko harremanak», 9) «Gurasoekiko harremanak» eta 10) «Gai ez izatearen sentsazioa».

\section{Bigarren zikloko talde esperimentala: pretesta eta postesta}

Bigarren zikloko talde esperimentalean ere aldeak antzematen dira pretestaren eta postestaren artean. Hasteko, 3. konparazioaren efektuaren tamaina altuak $(d=.69)$ adierazten digu antsietate-maila gutxitu egin dela programan parte hartu ondoren $(p=.039 ; t(38)=-2.140)$. Halaber, 5 . konparazioaren efektuak ere tamaina altua du $(d=1.08)$ eta nork bere buruarekiko duen konfiantza-maila hobetu dela ematen digu aditzera horrek $(p=.002 ; t(38)=-3.329)$.

Neurri txikiagoan bada ere, 1. («eskolarekiko jarrera ezkorra»), 7. («estres soziala») eta 10. («gai ez izatearen sentsazioa») konparazioen efektuaren tamaina ertaina da, halaber $(d=.48, d=.42$ eta $d=.47$ hurrenez hurren). Hiru aldagai horien kasuan, postest fasean pretestan baino puntuazio altuagoa edukitzeak dimentsioaren hobekuntza adierazten du. Alegia, eskolarekiko jarrera hobea izatea eta estres sozial txikiagoa izatea, eta gai izatearen sentsazioa areagotzea. 
Haurren arretaren eta ongizatearen sustatzea biofeedback bidezko...

Azkenik, 2. konparazioaren («irakasleekiko jarrera ezkorra») efektuaren tamaina ere ertaina izan arren $(d=.55)$, postestean lortutako puntuazioak pretestan lortutakoak baino baxuagoak dira, hortaz, uler daiteke irakasleekiko jarrera okerragoa dela saiakeraren ostean.

\section{4. taula}

Haurraren portaera: bigarren zikloko talde esperimentaleko pretesta eta postesta

\begin{tabular}{|c|c|c|c|c|c|c|c|c|c|}
\hline \multirow{2}{*}{$\begin{array}{l}\text { Pre-Post } \\
\text { konpara- } \\
\text { ketak }\end{array}$} & \multirow{2}{*}{$\mathrm{Bb}$} & \multirow{2}{*}{ Dt } & \multirow{2}{*}{$\begin{array}{c}\text { Bb } \\
\text { ohiko } \\
\text { akatsa }\end{array}$} & \multicolumn{2}{|c|}{$\begin{array}{c}\% 95 \\
\text { konfiantza tartea }\end{array}$} & \multirow{2}{*}{$t$} & \multirow{2}{*}{$\mathrm{gl}$} & \multirow{2}{*}{$\begin{array}{c}\text { Sig. } \\
\text { (bilaterala) }\end{array}$} & \multirow{2}{*}{$\begin{array}{c}\text { Cohen' } \\
\quad d\end{array}$} \\
\hline & & & & Azpitik & Goitik & & & & \\
\hline 1 & -.205 & .864 & .138 & -.485 & .075 & -1.483 & 38 & .146 & .48 \\
\hline 2 & .282 & 1.025 & .164 & -.050 & .614 & 1.719 & 38 & .094 & .55 \\
\hline 3 & -.641 & 1.871 & .300 & -1.247 & -.035 & -2.140 & 38 & .039 & .69 \\
\hline 4 & -.051 & 1.213 & .194 & -.444 & .342 & -.264 & 38 & .793 & .08 \\
\hline 5 & -.487 & .914 & .146 & -.783 & -.191 & -3.329 & 38 & .002 & 1.08 \\
\hline 6 & .026 & 1.739 & .279 & -.538 & .590 & .092 & 38 & .927 & .03 \\
\hline 7 & -.256 & 1.229 & .197 & -.655 & .142 & -1.302 & 38 & .201 & .42 \\
\hline 8 & .077 & 1.036 & .166 & -.259 & .413 & .464 & 38 & .645 & .15 \\
\hline 9 & .000 & .889 & .142 & -.288 & .288 & .000 & 38 & 1.000 & .00 \\
\hline 10 & -.385 & 1.648 & .264 & -.919 & .150 & -1.457 & 38 & .153 & .47 \\
\hline
\end{tabular}

Oharra: Lehen zutabeko 10 konparazio horiek BASC tresnaren aldagaietarako pretest fasean eta postest fasean lortutako neurriei dagozkie. 1) «Eskolarekiko jarrera ezkorra», 2) «Irakasleekiko jarrera ezkorra», 3) «Antsietatea», 4) «Autoestimua», 5) «Norberarekiko konfiantza», 6) «Depresioa», 7) «Estres soziala», 8) «Pertsonarteko harremanak», 9) «Gurasoekiko harremanak» eta 10) «Gai ez izatearen sentsazioa».

Hirugarren zikloko talde esperimentala: pretesta eta postesta

Hirugarren zikloko ikasleen artean, bada pretest fasetik postest fasera bitartean aldaketa estatistikoki esanguratsua izan duen konparazio bat, hain zuzen ere, 5 .a («Norberarekiko konfiantza»: $p=.016 ; t(30)=2.559$ eta $d=0.93$ ). Programa amaitu osteko fasean dimentsio honetako puntuazioa jaitsi egin zen, beraz, ikasleen konfiantza-maila hobetu zela esan daiteke.

Badira, halaber, aldaketaren efektuaren tamaina ertaina lortu duten konparazioak ere, nahiz eta atzemandako aldaketak estatistikoki esanguratsuak ez diren izan: 3. konparazioa («antsietatea»: $t(30)=-1.493$; $d=0.55)$, 4. konparazioa («autoestimua»: $t(30)=.895 ; d=.32$ ), 8. konparaketa («Pertsonarteko harremanak»; $t(30)=1.063 ; d=.39$ ) eta 9 . konparazioa («gurasoekiko harremanak»; $t(30)=-1.072 ; d=.39$ ). Emaitzak 
hobetu egin dira kasu guztietan, alegia, hirugarren zikloko ikasleek hobekuntza hauteman dute haien antsietate-mailan, autoestimuan eta gurasoekiko harremanetan. Pertsonarteko harremanak, ordea, ez bide dira hobetu, postestean lortutako puntuazioa txikiagoa baita pretestan lortu zutenaren aldean.

\section{5. taula}

\section{Haurraren portaera: hirugarren zikloko talde esperimentaleko pretesta eta postesta}

\begin{tabular}{|c|c|c|c|c|c|c|c|c|c|}
\hline \multirow{2}{*}{$\begin{array}{l}\text { Pre-Post } \\
\text { konpara- } \\
\text { ketak }\end{array}$} & \multirow{2}{*}{$\mathrm{Bb}$} & \multirow{2}{*}{$\mathrm{Dt}$} & \multirow{2}{*}{$\begin{array}{c}\mathrm{Bb} \\
\text { ohiko } \\
\text { akatsa }\end{array}$} & \multicolumn{2}{|c|}{$\begin{array}{c}\% 95 \\
\text { konfiantza tartea }\end{array}$} & \multirow{2}{*}{$t$} & \multirow{2}{*}{$\mathrm{gl}$} & \multirow{2}{*}{$\begin{array}{c}\text { Sig. } \\
\text { (bilaterala) }\end{array}$} & \multirow{2}{*}{$\begin{array}{c}\text { Cohen's } \\
d\end{array}$} \\
\hline & & & & Azpitik & Goitik & & & & \\
\hline 1 & .032 & .875 & .157 & -.289 & .353 & .205 & 30 & .839 & .07 \\
\hline 2 & -.097 & 1.300 & .234 & -.574 & .380 & -.414 & 30 & .682 & .15 \\
\hline 3 & -.484 & 1.805 & .324 & -1.146 & .178 & -1.493 & 30 & .146 & .55 \\
\hline 4 & .161 & 1.003 & .180 & -.207 & .529 & .895 & 30 & .378 & .32 \\
\hline 5 & .613 & 1.334 & .240 & .124 & 1.102 & 2.559 & 30 & .016 & .93 \\
\hline 6 & -.032 & 2.442 & .439 & -.928 & .864 & -.074 & 30 & .942 & .03 \\
\hline 7 & .097 & 1.375 & .247 & -.408 & .601 & .392 & 30 & .698 & .14 \\
\hline 8 & .194 & 1.014 & .182 & -.178 & .565 & 1.063 & 30 & .296 & .39 \\
\hline 9 & -.129 & .670 & . 120 & -.375 & .117 & -1.072 & 30 & .292 & .39 \\
\hline 10 & -.097 & 1.868 & .336 & -.782 & .589 & -.288 & 30 & .775 & .11 \\
\hline
\end{tabular}

Oharra: Lehen zutabeko 10 konparazio horiek BASC tresnaren aldagaietarako pretest fasean eta postest fasean lortutako neurriei dagozkie. 1) «Eskolarekiko jarrera ezkorra», 2) «Irakasleekiko jarrera ezkorra», 3) «Antsietatea», 4) «Autoestimua», 5) «Norberarekiko konfiantza», 6) «Depresioa», 7) «Estres soziala», 8) «Harreman interpertsonalak», 9) «Gurasoekiko harremanak» eta 10) «Gai ez izatearen sentsazioa».

\section{Kontrol-taldea: pretesta eta postesta}

Kontrol taldearen kasuan , 4. konparazioan atzeman ziren alde esanguratsuak $(p=.0003)$ pretest eta postest faseetan lorturiko puntuazioen artean («autoestimua»: $t(85)=3.086)$. Efektuaren tamainaren neurria, berriz, handia izan zen $(d=0.67)$. Hain zuzen, postesteko puntuazioak baxuagoak izan zirenez, ikasleen autoestimuak okerrera egin zuela ulertu daiteke.

Honekin zerikusia duen beste aldagai bat 10.a da («gai ez izatearen sentsazioa») Kasu honetan puntuazioek gora egin zuten postest fasean $(p=.012 ; t(85)=-2.581 ; d=.56)$, eta horrek adierazten du okerrera egin zuela ikasleen gaitasunekiko pertzepzioak ere. 
Haurren arretaren eta ongizatearen sustatzea biofeedback bidezko...

6. taula

Haurraren portaera: kontrol taldeko pretesta eta postesta

\begin{tabular}{|c|c|c|c|c|c|c|c|c|c|}
\hline \multirow{2}{*}{$\begin{array}{c}\text { Pre-Post } \\
\text { konpara- } \\
\text { ketak }\end{array}$} & \multirow{2}{*}{$\mathrm{Bb}$} & \multirow{2}{*}{ Dt } & \multirow{2}{*}{$\begin{array}{c}\text { Bb } \\
\text { ohiko } \\
\text { akatsa }\end{array}$} & \multicolumn{2}{|c|}{$\begin{array}{c}\% 95 \\
\text { konfiantza tartea }\end{array}$} & \multirow{2}{*}{$t$} & \multirow{2}{*}{$\mathrm{gl}$} & \multirow{2}{*}{$\begin{array}{c}\text { Sig. } \\
\text { (bilaterala) }\end{array}$} & \multirow{2}{*}{$\begin{array}{l}\text { Cohen's } \\
\quad d\end{array}$} \\
\hline & & & & Azpitik & Goitik & & & & \\
\hline 1 & -.105 & 1.006 & .109 & -.320 & .111 & -.965 & 85 & .338 & .20 \\
\hline 2 & -.047 & 1.659 & .179 & -.402 & .309 & -.260 & 85 & .795 & .06 \\
\hline 3 & -.186 & 2.061 & .222 & -.628 & .256 & -.837 & 85 & .405 & .18 \\
\hline 4 & .547 & 1.643 & .177 & .194 & .899 & 3.086 & 85 & .003 & .67 \\
\hline 5 & .140 & 1.465 & .158 & -.174 & .454 & .884 & 85 & .379 & .19 \\
\hline 6 & -.291 & 1.502 & .162 & -.613 & .031 & -1.795 & 85 & .076 & .39 \\
\hline 7 & -.035 & 1.537 & .166 & -.364 & .295 & -.210 & 85 & .834 & .05 \\
\hline 8 & -.093 & 1.411 & .152 & -.396 & .210 & -.611 & 85 & .543 & .13 \\
\hline 9 & .047 & .839 & .090 & -.133 & .226 & .514 & 85 & .608 & .11 \\
\hline 10 & -.349 & 1.253 & .135 & -.618 & -.080 & -2.581 & 85 & .012 & .56 \\
\hline
\end{tabular}

Oharra: Lehen zutabeko 10 konparazio horiek BASC tresnaren aldagaietarako pretest fasean eta postest fasean lortutako neurriei dagozkie. 1) «Eskolarekiko jarrera ezkorra», 2) «Irakasleekiko jarrera ezkorra», 3) «Antsietatea», 4) «Autoestimua», 5) «Norberarekiko konfiantza», 6) «Depresioa», 7) «Estres soziala», 8) «Pertsonarteko harremanak», 9) «Gurasoekiko harremanak» eta 10) «Gai ez izatearen sentsazioa».

\section{c) Programaren eraginak estres fisiologikoan (Emwave softwarea)}

Emwave software-aren bitartez, parte hartzaileek estresarekiko emandako erantzun fisiologikoak erregistratu ziren. Aintzat hartu diren indikatzaileak bi hauek izan dira: Bihotz-taupaden maiztasuna eta estres-maila (altua, ertaina, baxua eta guztira).

7. taula

Estres fisiologikoaren eboluzioa: Talde esperimentala

\begin{tabular}{lccccc}
\hline & 1. Saioa & 2. Saioa & 3. Saioa & 4. Saioa & 5. Saioa \\
\hline Bihotz maiztasuna & 84,84 & 88,26 & 86,55 & 86,68 & 87,91 \\
Estres maila altua & 55,56 & 27,82 & 28,86 & 31,62 & 36,06 \\
Estres maila ertaina & 16,90 & 15,60 & 22,95 & 21,28 & 23,91 \\
Estres maila baxua & 27,47 & 57,71 & 65,44 & 68,21 & 70,88 \\
\hline
\end{tabular}

Estres maila guztira $\quad \% 11,19 \quad \%-45,49 \quad \%-59,53 \quad \%-57,87 \quad \%-58,73$

Oharra. «Estres maila guztira» datuak hauxe adierazten du: Estres altua - (Estres ertaina + Estresa baxua). 
Talde esperimental gisa parte hartu duen lagin osoaren batezbestekoa aztertzen badugu, saio batetik bestera 7. taulako puntuazioak nola aldatzen diren ikusi ahalko dugu. Horrela, emaitza azpimarragarri bat bistaratuko dugu: «estres mailak guztira» duen jaitsiera ( $\% 11,19$ tik $\%$-58,73ra). Jaitsiera hori lehen saiotik bosgarrenera gertatu da. Hona hemen gainontzeko datuen irudikapen grafikoa (ikus 3. irudia).

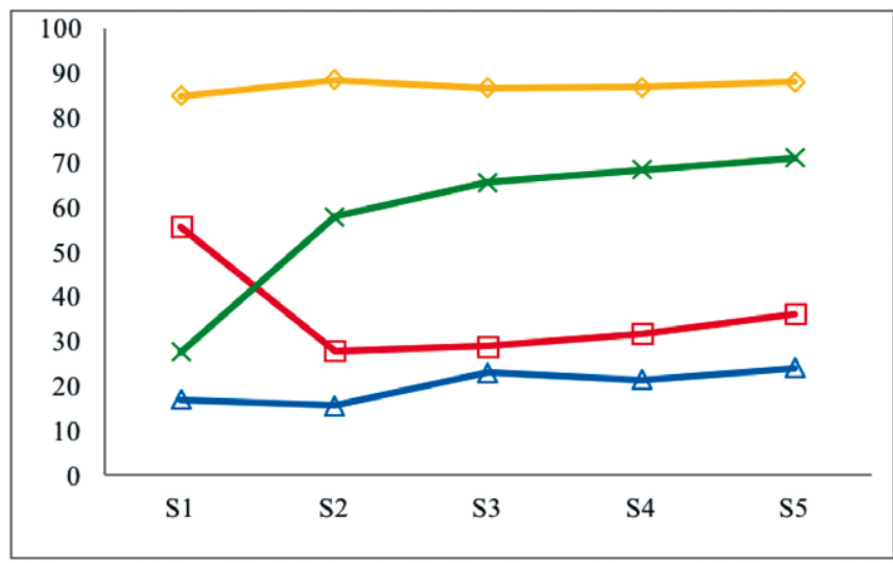

Bihotz maiztasuna

Estres baxua

Estres altua

Estres ertaina

3. irudia

Talde esperimentalaren estres fisiologikoaren eboluzioa

\section{EZTABAIDA ETA ONDORIOAK}

Ikerlan honen helburua biofeedbackaren teknikan oinarrituta diseinatutako esku-hartze programa baten eraginkortasun-maila aztertzea izan da; zehazki, haurren garapen psikologikoaren hiru arlo hauetan: arreta mailan, portaeran eta estres fisiologikoan. Ikus dezagun jarraian, zenbaterainokoa izan den programaren eraginkortasuna arlo bakoitzean eta zein neurritan datorren literatura zientifikoak aurreikusitakoarekin bat.

\section{Arreta-mailari dagozkion ondorioak}

Arreta-mailari dagokionez, baiezta daiteke parte hartzaileen arretamaila hobetu egin dela biofeedbackaren bidezko bost saioz osatutako entrenamenduaren ondoren. Zehazki, D2 Arreta Testaren aldagai hauetan lortu dira puntuazio hobeak postest fasean, prestest fasean lortutakoekin alderatuz: TR (emandako emaitza-kopurua), TA (asmatutakoak), TOT (abia- 
dura eta informazioa prozesatzeko kalitatea) eta CON (arreta selektiboa eta abiadura mentala). Alabaina, ez zen ezberdintasun estatistikoki esanguratsurik topatu pretest eta postest faseen arteko konparazioan honako bi aldagaien kasuan: $\mathrm{O}$ (hutsik uztea) eta $\mathrm{C}$ (akatsak egitea).

Emaitza hauek literatura zientifikoan aurkitutakoarekin bat datoz hein handi batean. Esaterako, Almansak eta bere taldekideek (2014) egindako ikerketa batean, 7 asteko iraupena izan zuen biofeedback programa bat erabili ostean, honako aldagaietan hobetu zuten Lehen Hezkuntzako hirugarren zikloko haurrek: zereginekiko orientazioa, ongizate psikologikoa eta arreta maila. Adin-tarte berdineko 65 ikaslerekin egindako beste lan batean (San Luis, López De la Llave eta Pérez-Llantada, 2013) aldagai hauetan izan zituzten hobekuntzak parte hartu zuten haurrek: arreta selektiboa eta mantendua, prozesatze kognitiboaren zehaztapena, arreta kontrola eta abiaduraren eta doitasunaren arteko oreka.

Badaude antzeko emaitzak atzeman dituzten bestelako ikerlanak ere. Adibidez, Britton-ek eta bere kideek egindakoa (2014). Ikerketa honetan ikusi zen mindfulness bidezko entrenamenduak ikasleen estresa gutxitu zuela eta arreta zein kontzentrazioa hobetu.

Gure ikerketan parte hartu duten irakasleen arabera, biofeedbackaren teknikaren erabilerak gelako giroan ere izan du eragin positiboa, eta haur bakoitzetik haratago, gela mailara zabaldu dira programaren onurak. Antzeko emaitzak aurkitu dituzte beste ikertzaile batzuek ere, Van de Weijer-Bergsma, Langenberg, Brandsma, Oort eta Bögels-ek (2014), adibidez, baieztatzen dute onuragarria izan daitekeela eskola-saioak hasi baino $5 \mathrm{mi}$ nutu lehenago intentsitate-maila baxuko entrenamendu mentala erabiltzea.

\section{Portaerari dagozkion ondorioak}

Ikerketa proiektu honetan proposaturiko beste helburu bat hauxe izan da: biofeedbackaren bitartez Lehen Hezkuntzako neska-mutilen portaerari dagozkion hainbat dimentsio hobetzea. Are zehatzago esanda, hobekuntza hauek espero ziren talde esperimentaleko haurrengan, erlaxazioaren, arnasketaren kontrolaren eta irudikapenaren inguruko bost saioko entrenamendua egin ostean: jarrera hobea eskolarekiko eta irakasleekiko; maila txikiagoak antsietatean, depresioan eta estres sozialean; gai izatearen sentsazio handiagoa eta autokonfiantza hobea; eta harreman hobeak bai gelako beste haurrekin eta baita gurasoekin ere.

Datuak aztertu ostean, ondoriozta daiteke bete egin direla aurreikuspenak eta programan parte hartu duten haurrek ia aldagai guztietan izan dituztela hobekuntzak. Aldagai bakarra izan da inolako aldaketa esangarririk erakutsi ez duena: «autoestimua». Edonola ere, kontrol taldearen kasuan, autoestimuaren jaitsiera atzeman da bost asteko epearen ostean (pretestetik postestera). Honek aditzera eman dezake erregulazio emozionalak ez duela 
eragin gehiegirik neska-mutilen autoestimuan, ez bada aldagai prebentibo gisa.

Emaitza hauek bat datoz antzeko ikerlanek lortutakoekin (Gunkelman eta Johnstone, 2005; Loo eta Barkley, 2005). Lan horietan aurkitu dute gelan zein patioan gertatzen diren gatazken kopurua txikitu egiten dela eta harreman sozialak hobetu egiten direla biofeedback teknika erabiliz, estres soziala gutxitzeko neurri gisa. Ildo beretik, ikasleen emozioak erregulatzeko gaitasuna hobetzearekin batera, haurrak bere inguruko lagun, guraso eta irakasleekiko pertzepzio positibo ere hobetuko litzateke (Pop-Jordanova eta Gucev, 2010).

\section{Estres fisiologikoari dagozkion ondorioak}

Emwave softwarearen bitartez lorturiko informazioari esker, ikusi ahal izan dugu zein izan den ikaslearen estres fisiologikoaren eboluzioa. Lehen saioan ikasleek konexio bat egin zuten bestelako teknikarik erabili gabe; ordutik, bigarren saiora hobekuntza handia ikusten da koherentzia fisiologikoan, soilik arnasketa teknika gehituta biofeedbackaren konexioari. Hortaz, egiaztatu da baliagarria izan dela programan parte hartu duten haurren egoera fisiologikoa orekatzeko orduan.

Bigarren saiotik hirugarren saiora ere hobekuntzak ikusi dira, baina ez dira hain nabarmenak izan; izan ere, arnasketa ziklikoaren teknika bera erabiltzen da bi saio hauetan eta haurrak barneratua dutela ikusten da. Laugarren saioan, berriro ere gorakada txiki bat ikusten da estresmailan, eta hori erlaziona daiteke ikusizko laguntza informatikoa kendu izanarekin. Saio honetan, ikasleek irudikapena erabiltzen dute eta ordenagailurik gabe, koloreko puxika bat paperean ikusten dute eta bere mugimendua imajinatu behar dute. Teknikan egin den aldaketa honek azaldu dezake laugarren eta bosgarren saioetan ikusi den estres-mailaren igoera txikia.

\section{Ikerlanaren mugak eta etorkizuneko lan ildoak}

Hasteko, ikerlan honen diseinuari begira ahultasun bat identifikatzen dugu kontrol-taldeari dagokionez. Izan ere, nahiz eta talde esperimentala eta kontrol-taldea baliokideak izan ezaugarrien zein tamainaren aldetik, D2 (arreta maila) eta BASC (garapena) tresnak ezarri zaizkie soilik prestest eta postest baldintzetan. Alegia, ez zaie indikatzaile fisiologikorik neurtu esku-hartze programan parte hartu ez duten neska-mutilei. EMWAVE bidezko neurketa ez egiteko arrazoia bikoitza izan da: batetik, denbora-muga kontrol taldeen kasuan eta, bestetik, esku-hartze programaren lehen eta azken saioek bat egitea talde esperimentaleko prestest eta postest uneetako 
neurketekin. Kontrol taldeko ikasleak aurrerago talde esperimentalera pasa daitezkeenez, ez zaie saiorik aurreratu nahi izan. Etorkizunean saiatuko gara hutsune hau betetzen, esaterako, kontrol-talde gisa hautatuz esku-hartze programan parte hartuko ez duten ikastetxeak.

Ikerlanaren bigarren muga gisa aipa dezakegu esku-hartze programaren iraupena bera. Izan ere, arnasketa zein imajinatze teknikak denborarekin eta modu jarraituan barneratzea litzateke egokiena, eta, ondoren, egunerokoan gerta daitezkeen egoera estresagarrietara ere hedatzea. Ezin ahaztu dezakegu biofeedback entrenamenduaren onurak nabarmenagoak direla zenbat eta gehiago praktikatu (Ricarte, Ros eta Latorre, 2015). Hortaz, etorkizuneko ikerkuntza-ildoei begira, interesgarria litzateke saioren bat gehitzea programazioari. Horrela, amaierako saioetan atzemandako estres-mailaren igoera horren arrazoia zein izan den aztertu ahal izango genuke; izan ere, agian irudikapenaren teknikari ohitua eta barneratzearekin izan dezake zerikusia. Horretarako, ez litzateke nahikoa izango bi saiorekin; beraz, saio gehigarriak diseinatu beharko lirateke.

Hirugarren ahulezia irakasleen estres maila eta emozioak kudeatzeko gaitasuna ez aztertu izana litzateke Hau, mugatzat baino, hutsunetzat har genezake. Aurrerantzean, programaren ebaluazioaren diseinuan irakasleen hainbat aldagai neurtu beharko lirateke, ondoren ikasleen emaitzekin batera aztertu ahal izan daitezen.

Amaitzeko aipatu nahi da Lehen Hezkuntzako haurren arreta eta ongizatea sustatzeko teknika berritzaile bat ezagutaraztea izan dela ikerlan honen ardatza. Horretarako, Biofeedbackaren bidezko esku-hartze programaren diseinua, inplementazioa eta ebaluazioa aurkeztu da. Espero da aurrerantzean ere, haurren ongizate psikologikoaren alde elkarlanean aritzea ikuspegi ezberdinetatik: hezkuntza, familia eta ikerkuntza.

\section{ERREFERENTZIAK}

Almansa, G., Budía, M.A., López, J.L., Márquez, M.J., Martínez, A.I., Palacios B... eta Sáenz-López, P. (2014). Efecto de un programa de Mindfulness sobre variables motivacionales y psicológicas en Educación Primaria. E-motion. Revista de Educación, Motricidad e Investigación, 3, 120-133.

Amon K.L. eta Campbell, F. (2008). Can children with AD/HD learn relaxation and breathing techniques through biofeedback video games? Australian Journal of Educational \& Developmental Psychology, 8, 72-84.

Andrasik, F. eta Flor, H. (2003). Biofeedback. In H. Breivik, W. Campbell, \& C. Eccleston (Edk.), Clinical pain management: Practical applications and procedures, 121-133 orr. London: Arnold.

Arguelles, L., McCraty, R. eta Rees, R.A. (2003). The HeartMath System: A narrative study of implementation experiences. Paper presented at the Annual Meeting of the Association for Supervision and Curriculum Development, San Francisco. 
Aritzeta, A., Soroa, G., Balluerka, N., Gorostiaga, A., Muela, A. eta Alliri, J. (2016). Reducing anxiety and improving academic performance through a biofeedback relaxation training program. Higher Education, 23, 77-89.

Blom, E.H., Olsson, E.M., Serlachius, E., Ericson, M. eta Ingvar, M. (2010). Heart rate variability (HRV) in adolescent females with anxiety disorders and major depressive disorder. Acta Paediatrica, 99, 604-611.

Brickenkamp, R. (2002). D2, Test de Atención. Madrid: TEA Ediciones.

Britton, W., Leep, N., Niles, H., Rocha, T., Fisher, N. eta Gold, J. (2014). A randomized controlled pilot trial of classroom-based mindfulness meditation compared to an active control condition in sixth-grade children. Journal of School Psychology, 52, 263-278.

Butnik, S. (2005). Neurofeedback in Adolescents and Adults with Attention Deficit Hyperactivity Disorder. Journal of Clinical Psychology, 61, 621-625.

Cannon, W.B. (1929). Bodily Changes in Pain, Hunger, Fear, and Rage. Appleton, New York.

Cole, P.M. eta Kaslow, N.J. (1988). Interactional and cognitive strategies for affect regulation: Developmental perspective on childhood depression. Cognitive processes in depression (orr. 310-343). New York: Guildford Press.

Friel, P. (2007). EEG Biofeedback in the Treatment of Attention Deficit/Hyperactivity Disorder. Alternative Medicine Review, 12, 146-151.

García, J. (2008). Psicología de la atención. Madrid: Síntesis.

Goleman, D. (2016). La Inteligencia Emocional: Nuevos Descubrimientos. Barcelona: No Ficción.

Graziano, P.A., Reavis, R.A., Keane, S.P. eta Calkins, S.D. (2007). The role of emotion in children's early academic success. Journal of School Psychology, 45, 3-19.

Gross, J.J. eta Thompson, R.A. (2007). Emotion regulation: conceptual foundations, in Handbook of Emotion Regulation, ed. J.J. Gross, 3-24 orr. New York, NY: Guilford Press.

Gunkelman, J. eta Johnstone, J. (2005). Neurofeedback and the Brain. Journal of Adult Development, 12(2/3), 93-98.

Harvard Mental Health Letter (2010). Neurofeedback for attention deficit hyperactivity disorder. www.health.harvard.edu/newsletters/Harvard_Mental

Immordino-Yang, M.H. eta Damasio, A. (2007). We feel, therefore we learn: The relevance of affective and social neuroscience to education. Journal of Mind, Brain and Education, 1, 3-10.

Jauregizar, J., Bernaras, E., Ibabe, I. eta Sarasa, M. (2012). Scholar, Clinical and Emotional Maladjustment in 8-12 School-Age Children: Adaptation of the Self-Report Version of the Behavior Assessment System for Children (BASC-S2) to the Basque-Speaking Population. Revista de Psicodidáctica, 17(2), 415-439.

Jiménez, J.E., Hernández, S., García, E., Díaz, A., Rodríguez, C. eta Martín, R. (2012). Test de atención D2: Datos normativos y desarrollo evolutivo de la atención en educación primaria. European Journal of Education and Psychology, 5, 93-106.

John, J.D. eta Gross, J.J. (2008). Gender Differences in Emotion Regulation: An fMRI Study of Cognitive Reappraisal. Group Processes \& Intergroup Relations, 11, 1-34. 
Haurren arretaren eta ongizatearen sustatzea biofeedback bidezko...

Karavidas, M.K., Lehrer, P.M., Vaschillo, E., Marin, H., Buyske, S., Malinovsky, I... eta Hassett, A. (2007). Preliminary results of an open label study of heart rate variability biofeedback for the treatment of major depression. Applied Psychophysiology Biofeedback, 32, 19-30.

Larsen, S. eta Sherlin, L. (2013). Neurofeedback: an emerging technology for treaing central nervous system dysregulation. The Psychiatric Clinics of North America, 36, 163-168.

Loo, S. eta Barkley, R. (2005). Clinical Utility of EEG in Attention Deficit Hyperactivity Disorder. Applied Neuropsychology, 12, 64-76.

McCraty, R., Atkinson, M. eta Tomasino, D. (2005). The coherent heart: Heartbrain interactions, psychophysiological coherence, and the emergence of system-wide order. Boulder Creek, CA: HeartMath Research Center, Institute of HeartMath.

Palomera, R., Fernández-Berrocal, P. eta Brackett, M. (2008). La inteligencia emocional como una competencia básica en la formación inicial de los docentes: algunas evidencias. Revista Electrónica de Investigación Psicoeducativa, 15(6), 437-454.

Pop-Jordanova, N. eta Gucev, Z. (2010). Game-based peripheral biofeedback for stress assessment in children. Pediatrics International, 52, 428-431.

Reinecke, M.A. eta Ginsburg, G.S. (2008). Cognitive-behavioral treatment of depression during childhood and adolescence. Abela JRZ, Hankin BL (edk.) Handbook of Depression in Children and Adolescents, 179-206 orr. New York: Guilford Press.

Reynolds, C.R. eta Kamphaus, R.W. (1992). Behavior Assessment System for Children. AGS Publishing.

Ricarte, J., Ros, L. eta Latorre, J. (2015). Mindfulness-Based Intervention in a Rural Primary School: Effects on Attention, Concentration and Mood.International. Journal of Cognitive Therapy, 8, 1-11.

San Luis, C., López de la Llave, A. eta Pérez-Llantada, M.C. (2013). Training to improve selective attention in children using neurofeedback through play. Revista de Psicopatología y Psicología Clínica, 18(3), 209-216.

Sánchez-Hernández, O., Méndez, F.X. eta Garber, J. (2014). Prevención de la depresión en niños y adolescentes: revisión y reflexión. Revista de Psicopatología y Psicología Clínica, 19, 63-76.

Soroa, M., Bernaras, E. eta Jauregizar, J. (2012). Haur-depresioa Lehen Hezkuntzako etapan: zertan datza eta irakasleek zer egin dezaketen. Uztaro, 81, 61-77.

Sterman, M.B. eta Egner, T. (2006). Foundation and practice of neurofeedback for the tratment of epilepsy. Applied Psychophysiology and Biofeedback, 31, 21-35.

Van de Weijer-Bergsma, E., Langenberg, G., Brandsma, R., Oort, F. eta Bögels, S. (2014). The Effectiveness of a School-Based Mindfulness Training as a Program to Prevent Stress in Elementary School Children. Springer Science, 5, 238-248.

Wadsworth, M.E. eta Hudziak, J.J. (2001). Latent class analysis of Child Behavior Checklist anxiety/depression in children and adolescents. Journal of the American Academy of Child \& Adolescent Psychiatry, 40, 106-114.

Zeman, J., Cassano, M., Perry-Parrish, C. eta Stegall, S. (2006). Emotion Regulation in Children and Adolescents. Journal of Developmental \& Behavioral Pediatrics, 27, 155-168. 